九州大学学術情報リポジトリ

Kyushu University Institutional Repository

\title{
Environmental Footprint Reduction of the Built- up Area in Metropolitan Regions by the Smart Development Plan: Lessons for Egypt
}

Osman, Taher

Faculty of Urban and Regional planning, Cairo University

Salem, Muhammad

Faculty of Urban and Regional planning, Cairo University

https://doi.org/10.5109/4102478

出版情報: Proceedings of International Exchange and Innovation Conference on Engineering \& Sciences (IEICES). 6, pp.134-140, 2020-10-22. Interdisciplinary Graduate School of Engineering Sciences, Kyushu University バージョン:

権利関係 : 


\title{
Environmental Footprint Reduction of the Built-up Area in Metropolitan Regions by the Smart Development Plan: Lessons for Egypt
}

\author{
Taher Osman, Muhamed Salem \\ Faculty of Urban and Regional planning, Cairo University \\ Corresponding author email: taher@kyudai.jp
}

\begin{abstract}
Smart development are underway to reduce environmental burdens and an energy saving. Methods of these projects for newly developed areas are already shown in several developed countries, but it for an existing builtup area is not yet. Therefore, this paper aimed to clarify an effect of an environmental footprint reduction and a saving energy when the smart technics apply to a built-up area. First, in this paper, several plans, which have different conditions of the spatial characteristics such as photovoltaic power generation are proposed for the development. Then, carbon dioxide emissions and an energy consumption are calculated for each plan. As a result, 4,254,645 kg-CO2 per year is emitted in present condition and the $45 \%$ of it is reduced by a photovoltaic power generation.
\end{abstract}

Keywords: Smart development; Environmental footprint; Built-up area; Carbon dioxide emission; Cairo Region

\section{INTRODUCTION}

\subsection{Background and Purpose}

Smart development projects are underway to reduce environmental burdens and an energy saving. In South Korea, Methods of the project for newly developed area are already shown, but it for an existing built-up area is not yet. In addition, the built-up area declines by decreasing population and decreasing low birthrate and aging population, and increasing vacant land and house, declining community. Therefore, this paper aimed to clarify an effect of an environmental footprint reduction and a saving energy when the smart technics apply to a built-up area.

Sustainable development was characterized as improvement which addresses [1] the issues of the current age without decreasing the capacity to address the issues of people in the future. Besides, the designs for future advancement ought to coordinate the financial and social difficulties while saving the characteristic equalization and security of essential normal procedures [2]. The issue of non-feasible improvement is as yet legitimate, as underlined in the most recent Report by the Club of Rome, which shows that all contemporary socio-natural issues could be related with the results of interminable development on a limited planet [3].

The thought of serious ecological debasement of the air, water and earth has a huge importance for the improvement and long-haul upkeep of the nature of human settlements [1]. This methodology ought to be basic for urban organizers, spatial advancement at authoritative levels, and for all arrangement producers. One of the arrangements concerning this issue is the Environmental Carrying Capacity (ECC) idea and instrument for supportable advancement of human settlements [4], just as for the evaluation of the supportability level of a given territory. The ECC is characterized as the degree of human movement, populace development, land use, physical improvement that nature can bolster without genuine corruption and irreversible changes. The ECC of given territory in this paper is evaluated utilizing two elements: Ecological Footprint (EF) and biocapacity (BC), which speak to devices for maintainable turn of events and strategy development. Consequently, the utilization of EF and BC would be significant for effective ECC execution [5] As urban communities are hotspots of human exercises and primary drivers of ozone harming substance (GHG) outflows, the manageability of contemporary urbanization is progressively on the plan [6].

Urban communities cannot get by without their more extensive hinterlands for assets and outflows sequestration. The area of occupations, living arrangements and different offices inside city areas emphatically influences the spatial example of versatility and utilization [7] Be that as it may, this example is consistently reconfigured by suburbanization and never-ending suburbia, which frequently cause hurtful environmental results, for example, the fracture of land use, the loss of biodiversity, or the expanding utilization of individual vehicle and higher petroleum product utilization [8]. The decentralization of creation and utilization pulverizes precisely urban communities' hinterlands. As suburbanization and never-ending suburbia persistently change the spatial example of urban areas, the social and natural requests of these procedures must be thought of.

Urban communities of Middle East were described by a dominatingly conservative urban structure before 1990 . There were hardly any highlights which took after Western sort suburbanization [9]. Other than arranging mediations, the development of rural zones was forestalled by inadequately composed open administrations, low degrees of vehicle proprietorship and restricted infrastructural systems. After 1990, in accordance with the approach of a free market framework and privatization of land, suburbanization abruptly heightened. The procedure of suburbanization, for example the decentralization of individuals and urban capacities (lodging, employments) is among the most contemplated marvels of post-communist urban progress [10]. Be that as it may, concentrates in the field have concentrated so far fundamentally on the financial settings of suburbanization, the recently developing examples of social isolation around urban areas, though, the natural interest of suburbanization, the manageability of post-communist urban change have been inadequately investigated. 


\subsection{Review of Related Studies}

There are many studies about smart technique. For example, there are studies that have shared a surplus electric power between blocks [11]. But those studies remain for the evaluation from the viewpoint of effectiveness and market economy by the proof experiment of the hardware technology in the new development area. In addition, they target the virtual space in the urban area and are not at the stage to be considered as method of town development with a town solving the city problem of the built-up area.

The idea of Ecological Footprint (EF) gives a significant all-encompassing device in surveying the manageability of urban zones [12]. Since its first application at the city level [13] maintainability investigations of urbanization by means of footprint evaluations have multiplied over the previous decades [14]. adding to the spread of this pointer. Exploration introduced in this paper decides to survey the spatial and fleeting changes of a supporting hinterland for post-communist Budapest and its urban locale by utilizing the Ecological Footprint Analysis (EFA). The essential point here is to investigate how unique purchaser ways of life impact the EF of a significant European metropolitan area (Budapest) and how it has been changed by suburbanization and neverending suburbia somewhere in the range of 2003 and 2013, when happier individuals moved from the center city to suburbia changing the utilization design and natural interest at the urban district level [15].

Human interest on biological system administrations has been consistently developing, as has the requirement for sufficient measurements to catch it. A generally perceived composite pointer of manageability, the Ecological Footprint estimates human interest on nature by surveying how much organically beneficial land and ocean zone is important to keep up a given utilization design. The reason for the idea is to decide the size of land utilized by people to address the issues of a specific populace gathering. In the most widely recognized methodology [16]. EF is made of six diverse land-use parts (cropland, touching area, timberland land, fishing grounds, carbon footprint/carbon take-up land and developed land) and estimated in bio profitability weighted hectares or worldwide hectares (gha). Ecological footprint counts initially centered around national-scale appraisals [17].

Afterward, approaches ascertaining the EF at the territorial, individual and even authoritative level have multiplied, adding new bits of knowledge to the maintainability banter [18]. Among the provincial level footprint counts, those concentrating on the ecological effects of urbanization has gotten particularly mainstream [19]. In spite of the fact that information for urbanized regions are not as reliably gathered and determined concerning country states and are in this manner, less equivalent, footprint estimations at urban level have gotten across the board in North America, Western Europe and China [20] recorded 63 city EF evaluations in the writing across 20 nations. Notwithstanding contextual analyses, relative ecological footprint appraisals of gatherings of urban communities have likewise showed up in the writing. For example, Isman et al. [21] investigated the carbon footprint subcomponent of EF for 15 Canadian urban areas as per registration metropolitan regions (CMA), while Baabou et al. [22] determined the footprint of 19 Mediterranean urban areas dependent on a multi-local information yield investigation utilizing information on normal family unit consumptions.

To compute a city's, EF one of two methodologies is for the most part followed: the top-down or the base up technique. The top-down or compound methodology depends on national ecological footprint information disaggregated by littler topographical territories. The crudest route is to utilize per capita national footprint esteems increased by the size of populace of a specific territory [23]. More refined variants of these figurines likewise think about nearby qualities, frequently riches pointers [24]. From one perspective, the significant advantage of this methodology is the moderately simple accessibility of information that can be acquired with minimal effort/exertion. Another bit of leeway is that missing information does not forestall the computation of a harsh gauge.

Papers focusing on the spatial type of urban areas for the most part concur that expanding driving can significantly build the carbon footprint. Starting here of view, the minimal city can ecologically be viewed as more ideal [25]. In any case, expanded urban thickness may not really decrease EF, as the gainful impacts of diminished driving can without much of a stretch be dissolved by rising utilization and carbon emanations. In the event that the footprint is determined at the family unit level, the situation of center urban communities might be far and away more terrible, as rural areas can for the most part be described by bigger family size [26]. This wonder was portrayed in detail on account of Helsinki Metropolitan Area [27].

The job of private area and position in the settlement order in the ecological heap of family units was additionally accentuated by Poom et al. [28] in Estonia, who found that the ecological footprint of occupants of Tallinn and other significant urban communities was fundamentally higher than those of rustic peripheries. The rural belt isn't homogeneous either, as the EF of rural gated networks and private parks where princely occupants live is fundamentally higher because of exceptional driving and elevated level of utilization [29] In different pieces of the rural zone like the country urban periphery or fringe provincial networks, the ecological footprint is by and large lower. Every one of these components propose that future exploration ought to look at pay, segment conditions and way of life in the translation of the footprint inside urban locales.

\subsection{Methodology}

Firstly, we build four indexes to evaluate an environmental performance in this study. Using them we evaluate the present environmental performance of the existing housing development in the built-up area. And we perform rebuilding simulation to rebuild a detached house in a multiple dwelling housing and analyze it how environmental performance changes when we introduced a smart technique and consider it.

\section{ENVIRONMENTAL EVALUATION}

\subsection{Evaluation Method}

In this chapter, we show the calculation method of four indexes (life cycle $\mathrm{CO} 2$, life cycle energy Consumption, quantity of photovoltaic power generation, quantity of $\mathrm{CO} 2$ absorption by the green space) that we built in reference to CASBEE [30]. 


\subsection{About CASBEE}

CASBEE (the Comprehensive Assessment System for Building Environmental Efficiency) is a system for evaluating and ranking buildings in terms of their environmental performance. CASBEE was developed by a committee set up in the Institute for Building Environment and Energy Conservation (IBEC) under the initiative of the Ministry of Land, Infrastructure and Transport (MLIT) in 2001. Since 2002, a series comprising various categories of CASBEE has been sequentially developed including CASBEE for New Construction, CASBEE for Existing Building, CASBEE for Renovation, and CASBEE for HI (Heat Island) as office building evaluation systems, as well as CASBEE for Urban Development as a building evaluation system. As part of this series, they decided to develop CASBEE for Home (Detached House). Other countries, particularly in Europe and North America, are also promoting such environmental performance assessment systems, including BREEAM and Eco-Homes in the United Kingdom and LEED in the United States. South Korea is disseminating CASBEE in line with this movement.

Calculation of life cycle $\mathrm{CO} 2$ for a building is usually a very large task, but CASBEE uses an approximate calculation method (i.e. Standard Calculation) in order to simplify the process. Specifically, a reference life cycle $\mathrm{CO} 2$ emission for each building type was set based on the life cycle $\mathrm{CO} 2$ of a building with level-3 performance in all assessment categories excluding "LR1 Energy" and is equivalent to the evaluation standard for building owners as referred to in the Energy Conservation Law. Using the reference values, calculation can be carried out more-or-less automatically, with some individual input, based on the $\mathrm{CO} 2$-related assessment results at each stage of a building life cycle (i.e. construction, operation, maintenance/upgrade/demolition). Therefore, in this study we calculate four indexes in reference to "CASBEE for Building (New Construction) 2014 edition" and "CASBEE for Home (Detached House) 2014 edition".

\subsection{Life Cycle CO2 Emission (kg-CO2/year)}

Life cycle $\mathrm{CO} 2$ emission was calculated it with structure, operation, maintenance/upgrade/demolition, three phases of the use. It multiplied the total of the $\mathrm{CO} 2$ emission basic unit per building area of each stage and building area of each building by it. Originally, the $\mathrm{CO} 2$ emission basic unit in the operative stage of each use demands one building by CASBEE evaluation software. However, we use a simpler method for it because we need enormous time. It is to calculate the basic unit that it inputs building area of the average of the target ground into CASBEE evaluation software and demanded it according to each use as a $\mathrm{CO} 2$ emission basic unit for the operative stage. Table1 is $\mathrm{CO} 2$ emission basic unit in CASBEE.

Life Cycle CO2 Emission (kg-CO2/year) = The total of the $\mathrm{CO} 2$ emission basic unit of each stage (kg$\mathrm{CO} 2 / \mathrm{m} 2 \cdot$ year $) \times$ Building area $(\mathrm{m} 2)$.
Table 1. CO2 Emission Basic Unit According to the Structure $(\mathrm{kg}-\mathrm{CO} 2 /$ year $\cdot \mathrm{m} 2)$

\begin{tabular}{ccccc}
\hline \hline $\begin{array}{c}\text { Structu } \\
\text { re }\end{array}$ & Stage & $\begin{array}{c}\text { Detache } \\
\mathrm{d} \\
\text { House }\end{array}$ & $\begin{array}{c}\text { Multiple } \\
\text { Dwelling } \\
\text { Housing }\end{array}$ & $\begin{array}{c}\text { Meeting } \\
\text { Place }\end{array}$ \\
\hline $\begin{array}{c}\text { Woode } \\
\mathrm{n}\end{array}$ & $\begin{array}{c}\text { Construction } \\
\text { Maintenance } \\
\text { /upgrade }\end{array}$ & 6.04 & 15.64 & 11.54 \\
& 2.35 & 8.02 & 12.81 \\
& /demolition & & & \\
& Managing & 31.45 & 100.54 & 73.05 \\
Steel & Construction & 13.48 & 15.64 & 11.54 \\
& Maintenance & 2.67 & 8.02 & 12.81 \\
& /upgrade & & & \\
& /demolition & & & \\
& Managing & 31.45 & 100.54 & 73.05 \\
Reinfor & Construction & 13.20 & 19.62 & 12.47 \\
ced & Maintenance & 2.58 & 8.37 & 13.43 \\
Concret & /upgrade & & & \\
$\mathrm{e}$ & /demolition & & & \\
& Managing & 31.45 & 100.54 & 73.05 \\
\hline \hline
\end{tabular}

\subsection{Life Cycle Energy Consumption (kWh/year)}

We convert it and perform energy of life cycle $\mathrm{CO} 2$ emission with a life cycle energy consumption using Busan Electric Power $\mathrm{CO} 2$ emission coefficient $(9.76 \mathrm{GJ} / 1000 \mathrm{kWh})$ and a primary energy conversion factor $(0.000672 \mathrm{t}-\mathrm{CO} 2 / \mathrm{kWh})$.

Life Cycle Energy Consumption $(\mathrm{kWh} / \mathrm{year})=$ Life Cycle $\mathrm{CO} 2$ Emission (kg-CO2/year) $\times 9.76$ (GJ/1000kWh) / $672(\mathrm{t}-\mathrm{CO} 2 / \mathrm{kWh})$

\subsection{Quantity of Photovoltaic Power Generation (kWh/year)}

The quantity of photovoltaic power generation is calculated by a loss coefficient other than annual quantity of sunlight, the solar battery capacity of the panel. The loss coefficient includes a temperature correction factor, the angle loss by the roof shape. It is originally desirable to calculate it in consideration of the influence of those all losses. However, in this study, the angle loss 0.7 by the land roof which can be considered, and the other loss factors are collectively calculated using the loss factor 0.73 which is generally used. We divide the roof area of each building by an area for one piece of the solar panel and assume the value that cut off a decimal the setting number of sheets. The sunlight quantity per day uses $3.61(\mathrm{kWh} / \mathrm{m} 2 \cdot$ day $)$ that averaged a value of Busan of sunlight quantity data of (1990 through 2009) for 20 years of "the quantity of sunlight database of NEDO". The solar panel uses a product of highest Company $\mathrm{T}$ of the power generation efficiency.

Quantity of Photovoltaic Power Generation (kWh/year) $=\{250(\mathrm{w}) \times$ the setting number of sheets $/ 1000\} \times 0.73$ $\times 0.70 \times 3.61(\mathrm{kWh} /$ year $) \times 365$

\subsection{Quantity of $\mathrm{CO} 2$ Absorption by the Green Space (kg-CO2/year)}

We calculate quantity of $\mathrm{CO} 2$ absorption when we assumed the park area of the target ground and the outward appearance area in the division a green space. The tree of the target ground plants, five kinds of evergreen broad-leaved trees established by city planning in the same ratio to a green space.

The Planting density shall be 0.05 a tree per square meter for tall tree (more than 4.0 meter), 0.2 a tree per square meter for middle tree (less than 2.5 meter more than 1.0 meter), 0.5 a tree per square meter for Shrub (around 0.5 meter). In this study, we utilized "The quantitative rating system of the atmosphere purification effect of the tree" listed in an atmosphere purification 
tree planting manual about a calculation method of the quantity of $\mathrm{CO} 2$ absorption of the tree.

Quantity of Carbon Dioxide Absorption by the Green Space $(\mathrm{kg}-\mathrm{CO} 2 /$ year $)=$ Green Space $(\mathrm{m} 2) \times$ Planting Density (a tree $/ \mathrm{m} 2) \times$ Quantity of annual $\mathrm{CO} 2$ absorption of one tree ( $\mathrm{kg}-\mathrm{CO} 2 /$ year)

\section{ENVIRONMENTAL PERFORMANCE EVALUATION OF THE HOUSING DEVELOPMENT IN THE BUILT-UP AREA}

We choose four housing developments of the built-up area where is different from the generation, scale and maintenance content. We perform an environmental performance evaluation every use and structure using four indexes that we built.

\subsection{Four target housing developments \\ 1) Buk District}

Buk District is in north central Busan. Buk-gu covers a surface of $38.30 \mathrm{~km}^{2}$ is home to about 335,000 people. there is characteristic that it has a larger building area of the average than other housing developments.

\section{2) Busanjin District}

Busanjin District is in central Busan. It has an area of $29.7 \mathrm{~km}^{2}$, and a population of about 410,000 , and home to a major shopping, entertainment, and business area. It is a relatively small housing development.

\section{3) Dongnae District}

Dongnae District is in northern Busan. It has a population of about 300,000 , and an area of 16.7 square kilometers. It was once a separate city, the principal port of southeastern Korea. Numerous historical relics are preserved in the area. It forms a housing development considered environment.

\section{4) Gangseo District}

Gangseo District is in the west side of Nakdong River in Busan. It has an area of $179.05 \mathrm{~km}^{2}$, and a population of about 66,000. It is a housing development of the energy saving.

\subsection{Environmental Performance Evaluation of Four Housing Developments}

In housing development of multiple dwelling housing and housing development with high building density, life cycle $\mathrm{CO} 2$ per development area has become a large value. In large housing development of old age has the large of the average building. Therefore, the photovoltaic power generation amount was high.

The reduction rate of life cycle $\mathrm{CO} 2$ in consideration of $\mathrm{CO} 2$ absorption by green space was highest at $25 \%$ in Dongnae Smart City project.

Table 2. Environmental Performance Evaluation of Housing Development in Buk District

\begin{tabular}{ll}
\hline \hline Summary & $\begin{array}{l}\text { Detached House : 76 houses } \\
\text { Multiple Dwelling Housing : } \\
7\end{array}$ \\
& $\begin{array}{l}\text { buildings } \\
\text { Duties facilities site } \\
\text { Population : 304 people } \\
\text { Population Density : 5.58 } \\
\text { people/km2 }\end{array}$ \\
& $\begin{array}{l}70,570.69 \\
119.83\end{array}$ \\
& 0.35 \\
Development Area (m2) & $22,504.88$ \\
Average of the Building Area & 0.32 \\
Average of the Building Coverage & \\
Ratio & \\
$\begin{array}{l}\text { Open Space Area (m2) } \\
\text { Open Space Area /Development } \\
\text { Area }\end{array}$ &
\end{tabular}

Life Cycle CO2 (kg-CO2/m2)

Life Cycle CO2/Development

Area (kg-CO2/year $\cdot \mathrm{m} 2)$

Life Cycle Energy Consumption (kWh/year)

Quantity of photovoltaic power

generation $(\mathrm{kWh} /$ year)

Quantity of photovoltaic power

generation /Development Area (

$\mathrm{kWh} /$ year $\cdot \mathrm{m} 2$ )

Quantity of Carbon Dioxide

Absorption by the Green

Space (kg-CO2/year)

The Ratio of the Quantity of

Carbon Dioxide Reduction By the Green Space

\section{REORGANIZATION SIMULATION BY THE MULTIPLE DWELLING HOUSING}

Vacant land and house increase in the recent housing development, and the compaction and restructuring directionality are shown in future. In this paper, the authors simulate it in housing development "Dongnae Smart City project" considered the environment including the detached house and multiple dwelling housing. And we perform simulation by the rebuilding of multiple dwelling housing that assumed the compaction and restructuring.

Table 3. Environmental Performance Evaluation of Housing Development in Busanjin District

\begin{tabular}{|c|c|}
\hline Summary & $\begin{array}{l}\text { Detached House : } 65 \text { houses } \\
\text { Multiple Dwelling Housing : } \\
0 \\
\text { Population : } 153 \text { people } \\
\text { Population Density : } 12.44 \\
\text { people/km2 }\end{array}$ \\
\hline Development Area (m2) & $16,832.44$ \\
\hline $\begin{array}{l}\text { Average of the Building Area } \\
(\mathrm{m} 2)\end{array}$ & 64.00 \\
\hline $\begin{array}{l}\text { Average of the Building Coverage } \\
\text { Ratio }\end{array}$ & 0.36 \\
\hline Open Space Area (m2) & 871.15 \\
\hline $\begin{array}{l}\text { Open Space Area /Development } \\
\text { Area }\end{array}$ & 0.05 \\
\hline Life Cycle CO2 (kg-CO2/m2) & $316,326.40$ \\
\hline $\begin{array}{l}\text { Life Cycle CO2 /Development Area } \\
(\mathrm{kg}-\mathrm{CO} 2 / \text { year } \cdot \mathrm{m} 2)\end{array}$ & 18.79 \\
\hline $\begin{array}{l}\text { Life Cycle Energy Consumption } \\
\text { (kWh/year) }\end{array}$ & $1,842,775.00$ \\
\hline $\begin{array}{l}\text { Quantity of photovoltaic power } \\
\text { generation }(\mathrm{kWh} / \text { year) }\end{array}$ & $594,050.60$ \\
\hline $\begin{array}{l}\text { Quantity of photovoltaic power } \\
\text { generation /Development Area ( } \\
\text { kWh/year } \cdot \mathrm{m} 2)\end{array}$ & 35.29 \\
\hline $\begin{array}{l}\text { Quantity of Carbon Dioxide } \\
\text { Absorption by the Green } \\
\text { Space (kg-CO2/year) }\end{array}$ & $50,358.52$ \\
\hline $\begin{array}{l}\text { The Ratio of the Quantity of } \\
\text { Carbon Dioxide Reduction By the } \\
\text { Green Space }\end{array}$ & 0.16 \\
\hline
\end{tabular}

Table 4. Environmental Performance Evaluation of Housing Development in Dongnae District

\begin{tabular}{ll}
\hline \hline Summary & $\begin{array}{l}\text { Detached House : 521 houses } \\
\text { Multiple Dwelling Housing : } \\
\text { 24 buildings } \\
\text { Population : 1822 people } \\
\text { Population Density : } 6.07 \\
\text { people/km2 }\end{array}$ \\
& $377,977.34$ \\
\hline $\begin{array}{l}\text { Development Area (m2) } \\
\text { Average of the Building Area }\end{array}$ & 136.42 \\
$\begin{array}{l}\text { Average of the Building } \\
\text { Coverage Ratio }\end{array}$ & 0.39 \\
$\begin{array}{l}\text { Open Space Area (m2) } \\
\text { Open Space Area /Development }\end{array}$ & 9.25
\end{tabular}

133,47287

$6,425,911.08$

$1,353,234.73$
16.06 
Area

Life Cycle CO2 (kg-CO2/m2)

$7,175,909.76$

18.99

$43,985,887.45$

Area (kg-CO2/year $\cdot \mathrm{m} 2)$

Life Cycle Energy Consumption

(kWh/year)

Quantity of photovoltaic power

generation (kWh/year)

Quantity of photovoltaic power

generation /Development Area

$(\mathrm{kWh} /$ year $\cdot \mathrm{m} 2)$

Quantity of Carbon Dioxide

Absorption by the Green

Space (kg-CO2/year)

The Ratio of the Quantity of

Carbon Dioxide Reduction By

the Green Space

\subsection{Summary of Dongnae Smart City project}

Dongnae Smart City project is housing development that introduces Environment-harmonious residential district model enterprise program and environmental improvement project of street. The site condition is noncosmetic surgery and gentle slope with ups and downs. It is creating a landscape that is familiar with the natural surroundings environment, such as creating an external structure that makes use of natural stones and trees [30].

\subsection{Precondition for the Multiple Dwelling Housing Rebuilding}

1) In an evaluation, the duties facilities site is excluded to intend for a housing development.

2) There are several sites where a detached house has not been yet built in present Dongnae Smart City project. So we calculate building area from site area using coverage ratio of the average of the detached house and we suppose that a detached house is built in 76 divisions all and evaluate it.

3) The multiple dwelling housing in the present conditions is located northeast. Thus, we rebuild it from the north side while considering lighting.

4) We rebuild nine detached houses in one multiple dwelling housing. The building area of the multiple dwelling housing to rebuild assumes it the average of an existing thing.

5) After having rebuilt it, the building area of the detached house and road where the building does not touch plants trees as open space.

Table 5. Environmental Performance Evaluation of Housing Development in Gangseo District

Summary

Detached House :53 houses Multiple Dwelling Housing : 0 Population : 153 people Population Density : 6.38 people/km2

\begin{tabular}{ll}
\hline $\begin{array}{l}\text { Development Area }(\mathrm{m} 2) \\
\text { Average of the Building Area } \\
(\mathrm{m} 2)\end{array}$ & $28,867.84$ \\
$\begin{array}{l}\text { Average of the Building Coverage } \\
\text { Ratio }\end{array}$ & 0.38 \\
$\begin{array}{l}\text { Open Space Area }(\mathrm{m} 2) \\
\text { Open Space Area /Development Area }\end{array}$ & $3,107.39$ \\
$\begin{array}{l}\text { Life Cycle CO2 (kg-CO2/m2) } \\
\text { Life Cycle CO2 /Development Area }\end{array}$ & $379,364.93$ \\
$\quad(\mathrm{~kg}-\mathrm{CO} 2 /$ year $\cdot \mathrm{m} 2)$ & 13.14 \\
$\begin{array}{l}\text { Life Cycle Energy Consumption } \\
\text { (kWh/year) }\end{array}$ & $2,491,877.99$ \\
$\begin{array}{l}\text { Quantity of photovoltaic power } \\
\text { generation (kWh/year) }\end{array}$ & $703,113.52$ \\
$\begin{array}{l}\text { Quantity of photovoltaic power } \\
\text { generation /Development Area }\end{array}$ & 24.36
\end{tabular}

Quantity of Carbon Dioxide

Absorption by the Green

Space (kg-CO2/year)

The Ratio of the Quantity of Carbon $\quad 0.22$

Dioxide Reduction By

the Green Space

6) The area of the parking lot and the bicycle parking lot of the multiple dwelling housing to rebuild calculates an area per one house from the present thing each. And we multiply the number of houses by it and assume it a parking lot area, a bicycle parking lot area.

Table 6. Summary of Smart Housing project in Dongnae Smart City project

\begin{tabular}{|c|c|}
\hline Architect & $\begin{array}{l}\text { Busan Housing and Planning } \\
\text { Association co.ltd }\end{array}$ \\
\hline Development Year (year) & 1996 \\
\hline Summary & $\begin{array}{l}\text { Detached House : } 76 \text { houses } \\
\text { Multiple Dwelling Housing : } 7 \\
\text { buildings Duties facilities site } \\
\text { Population : } 304 \text { people } \\
\text { Population Density : } 5.58 \\
\text { people/km2 }\end{array}$ \\
\hline Housing Development (m2) & $70,570.69$ \\
\hline Road Area (m2) & $16,056.22$ \\
\hline Open Space Area (m2) & $22,504.88$ \\
\hline $\begin{array}{l}\text { Average of the Building Area } \\
(\mathrm{m} 2)\end{array}$ & 120.21 \\
\hline $\begin{array}{l}\text { Average of the Building } \\
\text { Coverage Ratio }\end{array}$ & 0.34 \\
\hline $\begin{array}{l}\text { Average of the Multiple } \\
\text { Dwelling Housing Area (m2) }\end{array}$ & 373.80 \\
\hline
\end{tabular}

\subsection{General Environmental Performance Evaluation}

Exchanging amount of energy to $\mathrm{CO} 2$ (kg-CO2/year) as having converted life cycle $\mathrm{CO} 2$ emission into a life cycle energy consumption and add the quantity of photovoltaic power generation to quantity of $\mathrm{CO} 2$ absorption. We show around site figure when we rebuilt all a detached house of Dongnae Smart City project in nine multiple dwelling housings Table.7. We divide the calculation result of four indexes into life cycle $\mathrm{CO} 2$ emission and life cycle energy consumption and we become a list, a graph and consider it.

The Total Life Cycle CO2 Emission = Life Cycle CO2 Emission (kg-CO2/year) - Quantity of Photovoltaic Power Generation (kg-CO2/year) - Quantity of $\mathrm{CO} 2$ Absorption by the Green Space (kg-CO2/year)

\section{(1) Wooden Structure}

The wooden life cycle $\mathrm{CO} 2$ emission is reduced by approximately $80 \%$ by quantity of photovoltaic power generation and $\mathrm{CO} 2$ absorption by the green space. However, when rebuilding to multiple dwelling housing (9 buildings), the reduction rate drops to about $39 \%$ due to a decrease in quantity of photovoltaic power generation and a large amount of life cycle $\mathrm{CO} 2$ emissions from multiple dwelling housing than detached houses.

\section{(2) Steel Structure}

The life cycle $\mathrm{CO} 2$ emission per unit of steel structure is different from wooden structure. However, since the multiple dwelling housing and the meeting place are the same as in the case of wooden structure, the life cycle $\mathrm{CO} 2$ emissions when the nine buildings are rebuilt are almost the same as wooden structure. So, we can't see a big difference with wooden structure.

(3) Reinforced Concrete Structure

Life cycle $\mathrm{CO} 2$ emissions of present RC structure have 
increased by approximately 1.5 times than compare from the present wooden structure. The RC structure has a big most environmental footprint in three structures while it has the high durability.

\section{(4) Summary}

Environmental footprint reduction of the entire housing development is greatly influenced by the structure of the building and photovoltaic power generation, and the multiple dwelling housing is more environmental footprint than detached houses. The quantity of $\mathrm{CO} 2$ absorption by the green space is less effective in footprint reduction in tree species designated by the building standard of Dongnae Smart City project.

\section{LESSONS FOR THE GREATER CAIRO METROPOLITAN REGION}

In this study, we introduced a smart technique into the housing development in the built-up area and performed an environmental performance evaluation. And we aimed to clarify reduction of environmental footprint, the effect of multiple dwelling housing plan and smart technology introduction in the built-up area. In the simulation, the detached house was rebuilt as a multiple dwelling housing, and the environmental performance was evaluated by structure and use.

When rebuilding detached houses into multiple dwelling housing, the environmental performance was reduced. This is because the $\mathrm{CO} 2$ emissions per floor area are much larger in multiple dwelling housing than in detached houses and the effect of the quantity of $\mathrm{CO} 2$ absorption by the green space is small.

On the contrary, the effect of the quantity of photovoltaic power generation on environmental footprint reduction is very big. However, rebuilding to multiple dwelling housing reduces the roof area, the quantity of electricity generation decreases, and life cycle $\mathrm{CO} 2$ emissions increase. Looking at the case of wooden structure, life cycle $\mathrm{CO} 2$ emissions of present situation are reduced by about $80 \%$. On the other hand, we rebuild 9 buildings, it will be reduced to about $39 \%$. Looking at the structure, the wooden environmental footprint is the smallest.

In wooden structure and steel structure, large differences are not seen due to the same $\mathrm{CO} 2$ emissions per unit in multiple dwelling housings and meeting places. Life cycle $\mathrm{CO} 2$ emissions of present $\mathrm{RC}$ structure have increased by approximately 1.5 times the present wooden structure. In the process of consolidating buildings, in the case of building multiple dwelling housing, considering the collective form of houses, the volume of buildings, the method of utilizing open spaces, it is necessary to reduce the load by using smart technology.

\section{REFERENCES}

[1] G. e. a. Brundtland, eport of the World Commission on Environment and, oslo, 1987.

[2] A. Zielińska, "Durability Principles Versus Sustainable Development, Eco-development," Econ. Sociol, Vols. 5, 124-131, 2012.

[3] E. W. A. von Weizsäcker, "Come On! Capitalism, Short-termism,," Springer, New York., 2018.

[4] K. K. K. V. F. W. R. M. D. Stadler, Resource footprints and their ecosystem consequences., 2017.
[5] D. Edelman, "Carrying Capacity Based Regional Planning by National Institute of," Rotterdam, The Netherlands, Rotterdam, 1997.

[6] X. F. J. J. D. L. J. S. C. L. H. W. R. W. X. Liu, "Improvement of ecological footprint model in national nature reserve based on net primary production (NPP)," 2018.

[7] X. Q. Zhang, "The trends, promises and challenges of urbanisation in the world.," Habitat International, vol. 54, p. 241-252., 2016.

[8] A. \&. A. R. Poom, "How does the environmental load of household consumption Sustainability," Sustainability, Vols. 8(9), 799, 2016.

[9] I. C. \&. P. P. L. Bohnet, "Patterns, drivers and impacts of urban growth - A study Queensland, Australia from 1952 to 2031," Landscape and Urban, vol. 97, p. 239-248, 2010.

[10] S. Hirt, "Suburbanizing Sofia: Characteristics of post-socialist peri-urban change," Urban Geography, vol. 28(8), p. 755-780, 2007.

[11] J. \&. N. A. Kubeš, "Suburbs around the Czech provincial city of České Budějovice - Territorial arrangement and problems," Hungarian Geographical Bulletin, pp. 68(1), 65-78, 2019.

[12] W. E. Rees, "Ecological footprints and appropriated carrying capacity: What urban economics leave out," Environment and Urbanization, vol. 4, p. 120-130, 1992.

[13] M. Wackernagel, "1998," The ecological footprint of Santiago de Chile. Local Environment, p. 3(1), 1998.

[14] W. G. N. O.-P. C. G. M. \&. G. A. Baabou, "The ecological footprint of Mediterranean cities: Awareness creation and policy implications.," Environmental Science \& Policy, vol. 69, p. 94104, 2017.

[15] Z. \&. T. I. Kovács, Urban sprawl on the Danube: The impacts of suburbanization in Budapest., Oxford: Wiley-Blackwell, 2014.

[16] M. O. L. B. P. L. A. C. F. I. S. L. G. J. M. .. Wackernagel, "National natural capital accounting with the ecological footprint concept," Ecological Economics, vol. 29(3), p. 375-390, 1999.

[17] M. M. D. C. G. G. K. I. K. L. J. .. G. A. Borucke, "Accounting for demand and supply of the biosphere's regenerative capacity: The National Footprint Accounts' underlying methodology and framework.," Ecological Indicators, vol. 24, p. 518-533, 2013.

[18] B. \&. C. G. Q. Chen, "Modified ecological footprint accounting and analysis based on embodied exergy - A case study of the Chinese society 1981-2001.," Ecological Economics, pp. 61(2-3), 355-376, 2007.

[19] C. \&. K. D. M. Jones, "Spatial distribution of U.S. household carbon footprints reveals suburbanization undermines greenhouse gas benefits of urban population density,"

Environmental Science and Technology, vol. 48(2, p. 895-902, 2014.

[20] J. B. G. W. T. B. J. C. F. F. K. .. H. K. Minx, "Carbon footprints of cities and other human settlements in the UK," Environmental Research 
Letters, vol. 8(3), p. 1-10, 2013.

[21] M. A. M. K. C. L. D. I. K. \&. O.-P. C. Isman, "Ecological footprint assessment for targeting climate change mitigation in cities: A case study of 15 Canadian cities according to census metropolitan areas (CMA).," Journal of Cleaner Production, vol. 174, p. 1032-1043, 2018.

[22] W. G. N. O.-P. C. G. M. \&. G. A. Baabou, "The ecological footprint of Mediterranean cities: Awareness creation and policy implications.," Environmental Science \& Policy, vol. 69, p. 94 104, 2017.

[23] J. K. M. \&. R. W. E. Moore, "An urban metabolism and ecological footprint assessment of Metro Vancouver.," Journal of Environmental Management, vol. 124, p. 51-61, 2013.

[24] B. R. A. G. A. K. J. \&. W. M. wing, Calculation methodology for the National Footprint Accounts, Oakland: Global Footprint Network., 2010.

[25] I. C. D. \&. D. R. Muñiz, "The compensation hypothesis in Barcelona," Landscape and Urban Planning measured through the ecological footprint of mobility and housing, 2013.

[26] S. H. J. \&. J. S. Ala-Mantila, "Greenhouse gas implications of urban sprawl in the Helsinki metropolitan area," Sustainability, pp. 5, 44614478, 2013.

[27] J. \&. J. S. Heinonen, "Implications of urban structure on carbon consumption in metropolitan areas.," Environmental Research Letters, pp. 6(1), 1-9, 2011.

[28] A. I. A. A. M. I. A. A. R. L. L. G. .. Y. B. Rashid, "Ecological footprint of Rawalpindi; Pakistan's first footprint analysis from urbanization perspective," Journal of Cleaner Production, pp. 170, 362-368, 2018.

[29] S. K. S. B. A. General Association, " CASBEE for Building (New Construction) 2014 edition and CASBEE for Home (Detached House) 2014 edition.," 2014.

[30] S. T, "The urban structure and the environmental effect for the Smart City initiative, Proc.," in 10th Int. Simpo. On City Plann. Environ. Management in Asian Countries, 2016. 